\title{
A Microperfusion Study of Sucrose Movement across the Rat Proximal Tubule during Renal Vein Constriction
}

\author{
Norman Bank, William E. Yarger, and Hagop S. Aynedjian \\ From the Department of Medicine, New York University School of Medicine, \\ New York 10016
}

A B S T R A C T Constriction of the renal vein has been shown to inhibit net sodium and water reabsorption by the rat proximal tubule. The mechanism is unknown but might be the result of inhibition of the active sodium pump induced by changes in the interstitial fluid compartment of the kidney, or to enhanced passive backflux of sodium and water into the cell or directly into the tubular lumen. Since passive movement of solutes across epithelial membranes is determined in part by the permeability characteristics of the epithelium, an increase in the permeability of the proximal tubule during venous constriction would suggest that enhanced passive flux is involved in the inhibition of reabsorption. In the present experiments, isolated segments of rat proximal convoluted tubules were microperfused in vivo with saline while the animals were receiving ${ }^{14} \mathrm{C}$-labeled sucrose intravenously. In normal control animals, no sucrose was detected in the majority of the collected tubular perfusates. In rats with renal vein constriction ( $\mathrm{RVC}$ ), however, sucrose consistently appeared in the tubular perfusates. The rate of inflow of sucrose correlated with the length of the perfused segment, estimated by fractional water reabsorption. In another group of animals with renal vein constriction, inulin $-{ }^{14} \mathrm{C}$ was given intravenously and the proximal tubules similarly microperfused. Inulin did not appear in the majority of collected perfusates in these animals.

These observations indicate that a physiological alteration in the permeability of the proximal tubule occurs during RVC. Such an increase in permeability is consistent with the view that enhanced passive extracellular back-flux plays a role in the reduction of net sodium and water reabsorption in this experimental condition.

This work was presented at the Annual Meeting of the American Federation for Clinical Research in Atlantic City, 2 May 1970, and appears in abstract form in 1970. Clin. Res. 18: 521 .

Dr. Bank is a Career Scientist of the Health Research Council of New York City.

Received for publication 27 May 1970 and in revised form 12 October 1970.

\section{INTRODUCTION}

A number of recent experimental observations have suggested that renal sodium reabsorption may be regulated in part by colloid oncotic and hydrostatic pressures within the peritubular capillaries (1-7). The mechanism by which these physical forces acting in the vascular system influence sodium transfer by the tubular epithelium is unknown, but it has been postulated that the rate of uptake of the tubular reabsorbate by the capillaries may have an effect on the active sodium transport system, or may determine the rate of passive backdiffusion of sodium and water into the tubular cells or lumen $(4,7)$.

In order to study this problem, we have examined the permeability of the rat proximal tubule to sucrose and inulin (taken as extracellular labels) during renal vein constriction, an experimental condition shown by Lewy and Windhager (4) to markedly inhibit net sodium and water reabsorption. Segments of rat proximal tubules isolated by oil blocks were perfused in vivo with isotonic saline while trace amounts of either ${ }^{14} \mathrm{C}$-labeled sucrose or inulin were being infused intravenously. The collected perfusates were analyzed by liquid scintillation counting for influx of the molecules. In 19 of 21 perfusions in normal control animals, no sucrose was detected in the collected perfusates. In rats with constriction of the renal vein, however, sucrose consistently appeared in the collected perfusates, the amount increasing with the length of the perfused segment, as estimated by fractional water reabsorption. Inulin $-{ }^{14} \mathrm{C}$ did not appear in the majority of the collected perfusates of rats with RVC.' These observations demonstrate that the permeability of the proximal epithelium to sucrose increases during renal vein constriction. Since transepithelial passive flux is determined in part by the permeability characteristics of the epithelium, the observations are consistent with the view that increased back-flux of sodium and water via

\footnotetext{
${ }^{1}$ Abbreviations used in this paper: $\mathrm{CP}$, collected perfusate; GFR, glomerular filtration rate; $\mathrm{PW}$, plasma water; $\mathrm{RVC}$, renal vein constriction.
} 
an extracellular route contributes to the inhibition of proximal reabsorption in this experimental condition.

\section{METHODS}

Male white rats weighing $210-300 \mathrm{~g}$ were anesthetized with Inactin, tracheotomized, and placed on a heated animal table. The left external jugular vein was cannulated with $\mathrm{PE} 50$ polyethylene tubing and an infusion of Ringer's lactate solution containing trace amounts of either ${ }^{14} \mathrm{C}$-labeled sucrose $^{2}$ or inulin ${ }^{2}(0.4-0.8 \mu \mathrm{Ci} / \mathrm{min})$ was administered continuously at a rate of $0.05 \mathrm{ml} / \mathrm{min}$. A carotid artery was also cannulated with $\mathrm{PE} 50$ tubing for continuous recording of blood pressure by a Statham strain gauge (Model P 23 Dc) and Grass polygraph (Model 5D) (Grass Instrument Co., Quincy, Mass.). The left kidney was exposed through a lateral abdominal incision, dissected free of perirenal fat tissue, and immobilized with silicone grease in a plastic cup. The surface of the kidney was bathed with continuously flowing mineral oil warmed to $38^{\circ} \mathrm{C}$ and was illuminated with a fiber optic system. Rectal temperature was monitored with a thermistor and a tele-thermometer (Yellow Springs Instrument Co., Yellow Springs, Ohio) and the heat of the animal table adjusted to maintain body temperature at $37^{\circ}$ $38^{\circ} \mathrm{C}$. Timed urine collections were obtained from the left renal pelvis via a $\mathrm{PE} 50$ catheter, and periodic blood samples were obtained in heparinized capillary tubes from the cut tail. A larger volume of blood was obtained from the aorta at the end of the experiment.

In the first series of 12 experiments (five normal control animals and seven animals in which the vein of the left kidney was constricted with a seraphine clamp) sucrose- ${ }^{14} \mathrm{C}$ was given intravenously. The criteria used to determine the adequacy of the venous clamping procedure were those described by Lewy and Windhager (4); discoloration of the kidney was avoided, but the clamp was tightened enough to produce visible slowing of blood flow in the surface capillaries and an over-all increase in the size of the kidney. Proximal tubular hydrostatic pressure was measured with a micropipet (8), and the venous clamp adjusted until intratubular pressure rose $6 \mathrm{~mm} \mathrm{Hg}$ or more above the normal level of $12 \mathrm{~mm} \mathrm{Hg}$. Increased formation of fluid on the surface of the kidney was noted in these animals, which collected beneath the mineral oil. In order to minimize this potential source of contamination, a cotton wick was placed along the edge of the kidney to continuously drain off the surface fluid.

Perfusion of surface proximal convoluted tubules was carried out with a micropipet held in a micromanipulator and connected by thick-walled PE 20 tubing to a $10 \mu 1$ Hamilton syringe mounted on a Sage pump (Model 255-2). The Hamilton syringe was filled with mineral oil and polyethylene tubing and micropipet with $\mathrm{NaCl}, 154$ mmoles/liter, to which Lissamine green was added in a concentration of $0.2 \%$. The osmolality of this fluid was $314 \mathrm{mOsm} / \mathrm{kg}$. In in vitro calibration tests, the delivery of the perfusion system was found to be linear with pump settings between 10 and $50 \mathrm{nl} / \mathrm{min}$ and highly reproducible. The pump was set to deliver 25 $\mathrm{nl} / \mathrm{min}$, and once turned on, was kept running until the end of the experiment. Individual surface proximal tubules were perfused as follows. A long curved proximal tubular convolution on the surface of the kidney was selected and the perfusion pipet inserted at the mid-point of the convolution. The direction of free flow was determined by the color of the Lissamine green on each side of the pipet, and the

${ }^{2}$ New England Nuclear, Boston, Mass. number of more distal convolutions appearing on the surface was observed. If the tubule was judged satisfactory for perfusion, a long column (at least 5 tubule diameters) of heavy castor oil colored with Sudan black was injected with a second (collecting) micropipet into the tubule proximal to the perfusion pipet. The collecting pipet was then withdrawn and repeatedly thrust into the same segment in order to make multiple holes to allow fluid coming from the glomerulus to leak out onto the surface of the kidney. Perfusion of the tubule distal to the proximal oil block was continued for 1-2 min in order to wash out residual radioactive material in the lumen. The collecting pipet was then inserted into the perfused convolution farthest from the perfusion pipet, a long column of oil was injected quickly and allowed to flow distally, and collection of the perfusate started by adjustment of pressure applied to the collecting pipet. The period of collection was timed with a stopwatch. Almost all of the collections were between 3 and $6 \mathrm{~min}$. Care was taken to collect at a rate which maintained the proximal and distal oil blocks in a constant position, and which did not cause distention or collapse of the perfused convolutions. At the end of each collection, the collecting pipet was withdrawn rapidly into the layer of overlying mineral oil, in order to avoid contamination from surface fluid, and the tip of the pipet was sealed by drawing in mineral oil. At the end of the experiment, the collected perfusates, plasma, and urine samples were transferred to a constant-bore capillary tube under microscopic visualization and the volume of sample determined with an eyepiece micrometer (9). The samples were washed out of the capillary tube with water into counting vials containing $10 \mathrm{ml}$ of either a dioxane mixture (10) to which $0.5 \mathrm{ml}$ of Triton X-100 had been added or Scintisol (Isolab Inc., Elkhart, Ind.). A blank vial was made up at the end of each experiment by transferring a volume of the perfusion fluid remaining in the perfusion pipet to the constant bore capillary tube and then into a counting vial. All samples were counted for ${ }^{14} \mathrm{C}$ in a Nuclear Chicago liquid scintillation counter.

In a second series of eight experiments (two controls and six renal vein constriction), the methods were the same as for the first group, except that methoxy inulin $-{ }^{3} \mathrm{H}^{2}$ was added to the perfusion fluid in trace amounts in order to determine individual perfusion rates in vivo and to calculate per cent water reabsorption of the perfusate. In these experiments, the carbon channel of the liquid scintillation counter was set to exclude tritium. Because the tritium counts in each collected perfusate were always several hundred times greater than the ${ }^{14} \mathrm{C}$ counts, the spillover of ${ }^{14} \mathrm{C}$ into the ${ }^{3} \mathrm{H}$ channel was ignored. In vivo perfusion rates were calculated from the expression :

$$
\text { Collected/injected }\left[{ }^{3} \mathrm{H}\right] \times \text { collection rate. }
$$

Per cent reabsorption was calculated from:

$$
\left(1-\text { injected/collected }\left[{ }^{3} \mathrm{H}\right]\right) \times 100 \text {. }
$$

All of the collected perfusates were counted for 100-200 min each (five iterations), and the difference between the carbon counts of the sample and the perfusion fluid blank was tested for statistical significance by Student's $t$ test. The rate of movement of sucrose $-{ }^{14} \mathrm{C}$ into the tubular lumen, expressed as $\mathrm{cpm} /$ minutes of collection, was normalized for differences in plasma sucrose levels by dividing by the plasma water ${ }^{14} \mathrm{C}$ concentration at the mid-point of the collection period. The resultant equation is :

$$
\frac{\mathrm{CP} \mathrm{cpm} / \mathrm{min}}{\mathrm{PW} \mathrm{cpm} / \mathrm{n} 1}=\mathrm{n} 1 / \mathrm{min}
$$


TABLE I

Sucrose Clearance, Urine Flow, and Sodium Excretion for the Experimental Kidney

\begin{tabular}{|c|c|c|c|c|c|c|}
\hline & & $\begin{array}{c}\text { Sucrose } \\
\text { clearance }\end{array}$ & $\begin{array}{l}\text { Urine } \\
\text { flow }\end{array}$ & $\mathrm{UNaV}_{\mathrm{Na}}$ & $\mathrm{EF}_{\mathrm{Na}}$ & $\begin{array}{c}\text { Plasma } \\
\text { osmolality }\end{array}$ \\
\hline & & $\begin{array}{c}\text { ml/min } \\
\text { per } k g\end{array}$ & $\begin{array}{c}\mathrm{ml} / \mathrm{min} \\
\mathrm{per} \mathrm{kg}\end{array}$ & $\begin{array}{c}\mu E q / \min \\
\text { per } k g\end{array}$ & $\%$ & $\mathrm{mOsm} / \mathrm{kg}$ \\
\hline \multirow[t]{2}{*}{ Normal (8 rats) } & Mean & 3.83 & 0.019 & 1.29 & 0.26 & 316.7 \\
\hline & $\pm \mathrm{SE}$ & 0.26 & 0.01 & 0.33 & 0.08 & 9.4 \\
\hline \multirow[t]{2}{*}{ RVC (12 rats) } & Mean & 1.31 & 0.009 & 1.06 & 1.76 & 314.7 \\
\hline & $\pm \mathrm{SE}$ & 0.39 & 0.002 & 0.23 & 0.77 & 8.7 \\
\hline$P$ & & $<0.001$ & $\mathrm{NS}^{*}$ & $\mathrm{NS}^{*}$ & $\mathrm{NS}^{*}$ & \\
\hline
\end{tabular}

$* \mathrm{NS}=>0.05$.

where $\mathrm{CP}$ is the collected perfusate and $\mathrm{PW}$ is the plasma water. This expression has the dimensions of a clearance ( $\mathrm{nl} / \mathrm{min})$ and represents the volume of peritubular capillary plasma cleared of sucrose $-{ }^{14} \mathrm{C}$ per minute. As with other clearance expressions, no specific mechanism of transfer of sucrose into the tubular lumen is implied.

In a third group of three animals, the left renal vein was constricted as described above while the animals received inulin $-{ }^{14} \mathrm{C}$ intravenously at $0.8 \mu \mathrm{Ci} / \mathrm{min}$. Surface proximal tubules were microperfused with isotonic saline containing methoxy inulin- ${ }^{3} \mathrm{H}$ and the collected perfusates were counted for both ${ }^{14} \mathrm{C}$ and ${ }^{8} \mathrm{H}$ radioactivity as in the preceding group of experiments.

Stringent precautions were taken to avoid contamination of the perfusates. In spite of this, however, some samples were inadvertently contaminated. We assumed that collected perfusates in which the ${ }^{14} \mathrm{C}$ concentration was higher than that in the plasma, or in which the ${ }^{8} \mathrm{H}$ concentration was lower than in the injected perfusion fluid were grossly contaminated, and we discarded such samples. On the basis of these criteria, 13 samples were discarded out of a total of 91 perfusions.

In all experiments, plasma osmolality was measured in the sample of blood collected from the aorta at the end of the experiment, using a Precision Osmometer, Model 2007. Sodium concentration in plasma and urine was measured with an Instrumentation Laboratory flame photometer Model 143. Renal clearance of sucrose $-{ }^{14} \mathrm{C}$ for the experimental kidney was calculated from the expression $\mathrm{U} / \mathrm{P}_{14} \mathrm{c} \times$ urine flow rate. Using this clearance as an approximation of glomerular fil-

TABLE II

Appearance of Sucrose ${ }^{14} \mathrm{C}$ in Perfused Proximal Tubules of Normal Rats

\begin{tabular}{|c|c|c|c|c|c|c|c|c|c|}
\hline $\begin{array}{l}\text { Exp. } \\
\text { No. }\end{array}$ & $\begin{array}{c}\text { Tubule } \\
\text { No. }\end{array}$ & $\begin{array}{l}\text { Time of } \\
\text { collection }\end{array}$ & $\begin{array}{l}\text { Volume of } \\
\text { collection }\end{array}$ & $\mathrm{CP} \mathrm{cpm}$ & $P^{*}$ & $\mathrm{PW} \mathrm{cpm} / \mathrm{nl}$ & $\begin{array}{l}\text { Collection } \\
\text { rate }\end{array}$ & $\mathrm{CP} \mathrm{cpm} / \mathrm{min}$ & $\frac{\mathrm{CP}(\mathrm{cpm} / \mathrm{min})}{\mathrm{PW}(\mathrm{cpm} / \mathrm{nl})}$ \\
\hline & & $\min$ & $n l$ & & & & $n l / \min$ & & $n l / \min$ \\
\hline 1 & 1 & 4.0 & 56.6 & 0.395 & NS & 0.456 & 14.1 & & \\
\hline \multirow[t]{4}{*}{2} & 2 & 6.0 & 68.8 & 14.630 & $<0.001$ & 0.440 & 11.5 & 2.43 & 5.54 \\
\hline & 3 & 5.0 & 70.7 & 0.000 & NS & 0.426 & 14.1 & & \\
\hline & 4 & 5.0 & 77.8 & -1.145 & NS & 0.417 & 15.6 & & \\
\hline & 5 & 5.0 & 81.3 & -0.105 & NS & 0.398 & 16.2 & & \\
\hline \multirow[t]{4}{*}{3} & 6 & 5.0 & 47.7 & 0.510 & NS & 0.409 & 9.5 & & \\
\hline & 7 & 5.0 & 51.3 & 0.305 & $\mathrm{NS}$ & 0.423 & 10.2 & & \\
\hline & 8 & 4.0 & 56.6 & 0.000 & NS & 0.442 & 14.1 & & \\
\hline & 9 & 5.0 & 53.0 & 0.640 & NS & 0.520 & 10.6 & & \\
\hline \multirow[t]{3}{*}{4} & 10 & 4.0 & 67.2 & 0.745 & NS & 0.322 & 16.8 & & \\
\hline & 11 & 5.0 & 79.5 & 0.345 & NS & 0.159 & 15.9 & & \\
\hline & 12 & 5.0 & 83.0 & 0.015 & NS & 0.303 & 16.6 & & \\
\hline 5 & 13 & 7.0 & 77.8 & 2.230 & $<.01$ & 0.353 & 11.1 & 0.32 & 0.92 \\
\hline \multicolumn{2}{|c|}{ Mean } & 5.0 & 67.0 & 1.518 & & 0.390 & 13.6 & & \\
\hline \multicolumn{2}{|c|}{$\pm \mathrm{SE}$} & \pm 0.2 & \pm 3.5 & \pm 1.212 & & \pm 0.024 & \pm 0.7 & & \\
\hline
\end{tabular}

Abbreviations: $\mathrm{CP}=$ collected perfusate; $\mathrm{PW}=$ plasma water $; \mathrm{NS}=P>0.05$.

* $P$ values compare sample counts with blank. 
TABLE III

Appearance of Sucrose ${ }^{-14} \mathrm{C}$ in Perfused Proximal 7 ubules of $R V C$ Rats

\begin{tabular}{|c|c|c|c|c|c|c|c|c|c|}
\hline $\begin{array}{l}\text { Exp. } \\
\text { No. }\end{array}$ & $\begin{array}{c}\text { Tubule } \\
\text { No. }\end{array}$ & $\begin{array}{c}\text { Time of } \\
\text { collection }\end{array}$ & $\begin{array}{l}\text { Volume of } \\
\text { collection }\end{array}$ & $\mathrm{CP} \mathrm{cpm}$ & $P$ & $\mathrm{PW} \mathrm{cpm} / \mathrm{nl}$ & $\begin{array}{l}\text { Collection } \\
\text { rate }\end{array}$ & $\mathrm{CP} \mathrm{cpm} / \mathrm{min}$ & $\frac{\mathrm{CP}(\mathrm{cpm} / \mathrm{min})}{\mathrm{PW}(\mathrm{cpm} / \mathrm{nl})}$ \\
\hline & & $\min$ & $n l$ & & & & $n l / \min$ & & $n l / \min$ \\
\hline \multirow[t]{4}{*}{6} & 1 & 6.0 & 102.6 & 4.655 & $<0.001$ & 0.233 & 17.1 & 0.776 & 3.34 \\
\hline & 2 & 7.75 & 88.4 & 2.460 & $<0.001$ & 0.332 & 11.4 & 0.317 & 0.95 \\
\hline & 3 & 6.0 & 72.4 & 9.835 & $<0.001$ & 0.344 & 12.1 & 1.639 & 4.77 \\
\hline & 4 & 8.0 & 49.4 & 4.82 & $<0.001$ & 0.301 & 6.2 & 0.602 & 2.01 \\
\hline \multirow[t]{3}{*}{7} & 5 & 2.5 & 28.3 & 2.62 & $<0.001$ & 1.429 & 11.3 & 1.048 & 0.73 \\
\hline & 6 & 4.0 & 70.7 & 8.12 & $<0.001$ & 1.215 & 17.7 & 2.030 & 1.67 \\
\hline & 7 & 6.0 & 58.3 & 4.26 & $<0.001$ & 0.410 & 9.7 & 0.711 & 1.73 \\
\hline \multirow[t]{3}{*}{8} & 8 & 5.0 & 72.5 & 24.95 & $<0.001$ & 0.470 & 14.5 & 4.99 & 10.60 \\
\hline & 9 & 9.0 & 61.8 & 6.53 & $<0.001$ & 0.582 & 6.9 & 0.726 & 1.25 \\
\hline & 10 & 5.0 & 88.4 & 10.2 & $<0.001$ & 0.710 & 17.7 & 2.04 & 2.88 \\
\hline \multirow[t]{5}{*}{9} & 11 & 4.25 & 26.5 & 3.84 & $<0.001$ & 0.463 & 6.2 & 0.904 & 1.95 \\
\hline & 12 & 4.0 & 63.6 & 4.49 & $<0.001$ & 0.483 & 15.9 & 1.122 & 2.32 \\
\hline & 13 & 4.0 & 65.4 & 4.85 & $<0.001$ & 0.483 & 16.3 & 1.211 & 2.51 \\
\hline & 14 & 4.0 & 63.6 & 6.22 & $<0.001$ & 0.485 & 15.9 & 1.555 & 3.20 \\
\hline & 15 & 5.0 & 63.6 & 2.885 & $<0.001$ & 0.483 & 12.7 & 0.577 & 1.18 \\
\hline 10 & 16 & 4.0 & 49.5 & 6.34 & $<0.001$ & 0.615 & 12.4 & 1.585 & 2.58 \\
\hline \multirow[t]{2}{*}{11} & 17 & 4.0 & 65.4 & 2.68 & $<0.01$ & 0.605 & 16.3 & 0.671 & 1.11 \\
\hline & 18 & 5.0 & 68.9 & 10.14 & $<0.001$ & 0.751 & 13.8 & 2.028 & 2.70 \\
\hline 12 & 19 & 5.0 & 95.4 & 6.66 & $<0.001$ & 0.638 & 19.1 & 1.332 & 2.09 \\
\hline \multirow{2}{*}{\multicolumn{2}{|c|}{$\begin{array}{l}\text { Mean } \\
\pm \mathrm{SE}\end{array}$}} & 5.2 & 66.0 & 6.66 & & 0.581 & 13.3 & 1.394 & 2.61 \\
\hline & & \pm 0.4 & \pm 4.5 & \pm 1.17 & & \pm 0.068 & \pm 0.9 & \pm 0.247 & \pm 0.50 \\
\hline
\end{tabular}

tration rate (GFR) (11), the filtered load of sodium and the excreted fraction of filtered sodium $\left(\mathrm{EF}_{\mathrm{Na}}\right)$ were also calculated. All calculations and statistical analyses were carried out on an Olivetti-Underwood Programma 101.

\section{RESULTS}

The clearance data for the experimental kidney in the 20 animals given sucrose intravenously are summarized in Table I. As can be seen, renal vein constriction reduced sucrose clearance by about $65 \%$. Urine flow and $\mathrm{U}_{\mathrm{Na}} \mathrm{V}$, however, fell only slightly, the difference from the control group being not statistically significant. The excreted fraction of filtered sodium, $\mathrm{EF}_{\mathrm{Na}}$, showed a tendency to rise, but the difference from the control animals was not significant at the 0.05 level. These observations are similar to those made by Lewy and Windhager (4), and suggest that the degree of renal vein constriction in our animals was of the same order of magnitude as in their study. Plasma osmolality was approximately the same in the two groups of animals and was close to that of the injected perfusion fluid, i.e. $314 \mathrm{mOsm} / \mathrm{kg}$.

In Table II are presented the microperfusion data for the five normal control animals in the first series of experiment. As can be seen, in 11 out of 13 perfusions of surface proximal tubules, the radioactivity of the collected perfusates was not significantly different from that of the blank. Two samples in this group of animals, not shown in the table, were found to have significant ${ }^{14} \mathrm{C}$ counts but were considered to be grossly contaminated on the basis of the criteria outlined under Methods, and were excluded. Two other samples, shown in Table II, had counts significantly above background but could not be excluded. These observations indicate that in the majority of the perfusions, the proximal and distal oil blocks adequately prevented contamination from free-flow tubular fluid.

Table III presents the microperfusion data for the seven animals in the first series of experiments with constriction of the left renal vein. In sharp contrast to the observations in the control animals, sucrose $-{ }^{14} \mathrm{C}$ was found in all of 24 collected perfusates. Five of these perfusions were excluded as grossly contaminated, and the remaining 19 are shown in Table III. As can be seen, the difference between the experimental and control animals cannot be accounted for by differences in the time of perfusion or the volume of the collected perfusate, since these were almost identical in the two groups. The average concentration of sucrose $-{ }^{14} \mathrm{C}$ in plasma water was higher 
TABLE IV

Effect of Renal Vein Constriction on Sucrose- ${ }^{-14} \mathrm{C}$

\begin{tabular}{|c|c|c|c|c|c|c|c|}
\hline \multirow[b]{2}{*}{ Time } & \multicolumn{7}{|c|}{ Collected perfusate } \\
\hline & $\begin{array}{c}\text { Perfu- } \\
\text { sion } \\
\text { No. }\end{array}$ & Vol. & $\begin{array}{l}\text { Collec- } \\
\text { tion } \\
\text { rate }\end{array}$ & $\begin{array}{c}\mathrm{CP} / \mathrm{IP} \\
{ }^{3} \mathrm{H}\end{array}$ & $\begin{array}{l}\text { Perfu- } \\
\text { sion } \\
\text { rate }\end{array}$ & $\begin{array}{l}\text { Fractional } \\
\text { reabsorp- } \\
\text { tion }\end{array}$ & $\begin{array}{c}\mathrm{CP} \\
\mathrm{cpm}\end{array}$ \\
\hline $\min$ & & $n l$ & $n l / \min$ & & $n l / \min$ & $\%$ & \\
\hline 0-290 & \multicolumn{7}{|c|}{ Infuse Ringer's lactate + sucrose- ${ }^{14} \mathrm{C} 16.7 \mu \mathrm{Ci} / \mathrm{ml}, 0.05 \mathrm{ml} / \mathrm{min}$} \\
\hline $55-290$ & \multicolumn{7}{|c|}{ Renal vein partially constricted, intratubular pressure $20 \mathrm{~mm} \mathrm{Hg}$} \\
\hline $107-111$ & 1 & 32 & 8.0 & 2.03 & 16.2 & 50.8 & 2.333 \\
\hline $114-269$ & & & & & & & \\
\hline $168-171$ & 2 & 27 & 10.6 & 1.65 & 17.5 & 39.3 & 1.033 \\
\hline $198-202$ & 3 & 37 & 9.3 & 1.46 & 13.5 & 31.4 & 1.308 \\
\hline $260-264$ & 4 & 74 & 18.6 & 1.14 & 21.1 & 12.0 & 0 \\
\hline
\end{tabular}

Abbreviations: $\mathrm{IP}=$ injected perfusate; $\mathrm{CP}=$ collected perfusate; $\mathrm{PW}=$ plasma water.

in the experimental animals than in the controls, but there was considerable overlap and in many instances the values were within the same range in the two groups. The average clearance of sucrose from the peritubular capillaries calculated in the last column was $2.61 \mathrm{nl} / \mathrm{min}$.

Although the usual sources of contamination seemed to have been ruled out in the control group of animals, it is possible that the perfusates in the animals with venous constriction might be more prone to contamination because of the increased hydrostatic pressure within the tubular lumen and interstitial compartment, and because of increased amounts of surface fluid. Higher intratubular pressure might lead to a greater tendency of free-flow tubular fluid to leak around the oil blocks, and higher interstitial pressure might cause fluid to enter the perfused segments around the two pipets. Because of these possible sources of error, a second series of experiments was carried out in which sucrose influx was correlated with an estimate of the length of the perfused segment. For this purpose, inulin ${ }^{-} \mathrm{H}$ was added to the injected perfusion fluid and the per cent reabsorption of the perfusion fluid determined from injected/collected ${ }^{3} \mathrm{H}$ ratios. The results of a single experiment are shown in detail in Table IV, and those for all eight experiments in this group in Table V and Fig. 1. No perfusions in the two control animals were excluded, but 6 out of 30 perfusions were excluded in the experimental group because of gross contamination.

The perfusion rate in vivo for this group of animals, calculated from equation 1 , was found to be $17.3 \mathrm{nl} / \mathrm{min}$ $( \pm 1.4 \mathrm{SE})$, a value lower than the $25 \mathrm{nl} / \mathrm{min}$ determined by in vitro calibration of the perfusion system. The reason for this difference is not entirely clear but may be due to partial plugging of the perfusion pipet tip by renal tissue or to occasional touching of the pipet tip against the side of the tubule.
As shown by the individual perfusion data in Table $\mathrm{V}$ and the corresponding linear regression lines plotted in Fig. 1, the clearance of sucrose $-{ }^{14} \mathrm{C}$ by the proximal tubules increased with increasing values of fractional reabsorption. As a group, the tubular clearance of sucrose in these animals was slightly lower than in the animals shown in Table III. The difference is probably due to the fact that the longest possible segments were perfused in the animals shown in Table III, whereas the length of perfused segment was purposely varied in the experiments shown in Table V. Since the degree of venous constriction and the inhibition of sodium reabsorption probably varied from one animal to another, the values for fractional reabsorption among the different animals shown in Table $\mathrm{V}$ probably do not represent equivalent lengths of tubule. Moreover, the length of perfused segment implied by fractional reabsorption in the experimental group cannot be compared directly with that in the control animals in which sodium reabsorption was not inhibited. Nevertheless, the data clearly show that in individual animals sucrose clearance correlated with the length of the perfused segment, indicating a physiological phenomenon. In eight perfusions in two control animals, shown in Fig. 1, there was again no detectable influx of sucrose over a range of fractional reabsorption from 17 to $41 \%$.

In Table VI are shown the results of perfusions of the proximal tubules of three rats with $\mathrm{RVC}$, given inulin $-{ }^{14} \mathrm{C}$ intravenously. Intratubular hydrostatic pressure was between 20 and $25 \mathrm{~mm} \mathrm{Hg}$, a range comparable to that in the other two groups of RVC rats. As shown in Table VI, microperfusion rates, fractional reabsorption of the perfusion fluid, and the level of radioactivity in the plasma were also comparable to those in the other groups of RVC animals given sucrose ${ }^{-14} \mathrm{C}$ intravenously. In contrast to the sucrose experiments, however, inulin could 


\begin{tabular}{|c|c|c|c|c|c|c|}
\hline \multicolumn{2}{|c|}{ Collected perfusate } & \multicolumn{5}{|c|}{ Urine } \\
\hline $\begin{array}{l}\mathrm{PW} \\
\mathrm{cpm} / \mathrm{nl}\end{array}$ & $\frac{\mathrm{CP}(\mathrm{cpm} / \mathrm{min})}{\mathrm{PW}(\mathrm{cpm} / \mathrm{nl})}$ & Flow & $\begin{array}{l}\text { Sucrose } \\
\text { clear- } \\
\text { ance }\end{array}$ & $\mathrm{U}_{\mathrm{Na}}$ & $\mathrm{U}_{\mathrm{Na}} \mathrm{V}$ & $\mathrm{EF}_{\mathrm{Na}}$ \\
\hline & $n l / \min$ & $\begin{array}{l}\mu l / \min \\
\operatorname{per~} \mathrm{kg}\end{array}$ & $\begin{array}{l}\mathrm{ml} / \mathrm{min} \\
\mathrm{per} k g\end{array}$ & $m E q /$ liter & $\begin{array}{c}\mu E q / \min \\
\text { per } k g\end{array}$ & $\%$ \\
\hline 0.416 & 1.37 & & & & & \\
\hline & & 0.0091 & 0.117 & 155 & 1.41 & 7.4 \\
\hline 0.542 & 0.74 & & & & & \\
\hline 0.602 & 0.53 & & & & & \\
\hline 0.764 & 0.00 & & & & & \\
\hline
\end{tabular}

be detected in only 4 out of 14 of the collected perfusates. In the four collected perfusates with some detectable radioactivity, the differences in counts between the samples and blank were significant only at the $0.02-0.05$ level, and the cpm were much lower than was found in the animals given sucrose $-{ }^{14} \mathrm{C}$ intravenously.

\section{DISCUSSION}

The present observations suggest that under control conditions, the proximal tubule epithelium of the rat is relatively impermeable to sucrose. In 19 out of 21 microperfusions in normal animals, no ${ }^{14} \mathrm{C}$-labeled sucrose was detected in the perfusates of the proximal tubule at a time when easily detectable amounts were present in the plasma. Because of the limitations of the methods of liquid scintillation counting, it is possible that very small amounts of sucrose did cross the proximal epithelium of the normal rats but could not be measured. In sharp contrast, in the animals with constriction of the renal vein of the experimental kidney, significant quantities of sucrose- ${ }^{14} \mathrm{C}$ were found in 42 out of 43 collected perfusates. It seems unlikely that the difference between the control and experimental animals could have been due to technical errors. First, the fact that no radioactivity was found in the majority of the samples from the normal animals indicates that ordinary sources of contamination, such as free-flow tubular fluid seeping around the oil blocks into the perfused segments or surface fluid entering the collecting pipet, were effectively eliminated. Although the risk of contamination seems to have been greater in the experimental animals, the data shown in Tables IV and $\mathrm{V}$ and in Fig. 1 clearly demonstrate a correlation between the rate of sucrose entry into the lumen and the length of the perfused segment, as estimated by fractional reabsorption. Contamination of the perfusate would not be expected to show such a relationship. Furthermore, the experiments in which inulin ${ }^{-14} \mathrm{C}$ was given intravenously, shown in Table VI, lend additional support to the validity of the sucrose observations. Leakage of fluid into the perfused segment from around the oil blocks or from tears in the epithelium would result in as much inulin being present in the perfused segments as was found in the sucrose experiments. As can be seen from Table VI, however, only 4 out of 14 collected perfusates showed any detectable amounts of inulin, and in these the level of radioactivity was only barely above background. Furthermore, there was no apparent relationship between the length of the perfused segment and the appearance of inulin in these animals. These considerations lead us to conclude that the observations with sucrose were the result of a physiological increase in the permeability of the epithelium related to renal vein constriction.

Sucrose is generally considered not to diffuse across plasma membranes (12), and to our knowledge no active transport mechanism for sucrose has been described. It therefore seems reasonable to assume that, whatever the precise mechanism for the movement of sucrose into the tubular lumen in the RVC rats, the pathway was extracellular and the influx was passive. Two possible extracellular pathways can be considered. Bentzel, Parsa, and Hare (13) found that the cells of the proximal tubule of necturus kidney show increased vacuolization during osmotically induced flow from the peritubular blood into the lumen. They suggested that a pathway for influx of fluid under these experimental conditions is via formation of pinocytotic vacuoles at the basal membrane of the cells and transfer of the vacuoles to the tubular lumen. It seems unlikely that such a mechanism could account for the increased influx of sucrose observed in the present experiments, since no osmotic gradient was present to stimulate vacuole formation. Moreover, transfer of fluid 
TABLE V

Relationship between Sucrose-14C Influx and Tubular Length, Estimated by

Fractional Reabsorption of Water, in Rats with RVC

\begin{tabular}{|c|c|c|c|c|c|}
\hline $\begin{array}{l}\text { Exp. } \\
\text { No. }\end{array}$ & $\begin{array}{c}\text { Tubule } \\
\text { No. }\end{array}$ & $\begin{array}{l}\text { Fractional } \\
\text { reabsorp- } \\
\quad \text { tion }\end{array}$ & $\frac{\mathrm{CP}(\mathrm{cpm} / \mathrm{min})}{\mathrm{PW}(\mathrm{cpm} / \mathrm{nl})}$ & $r^{*}$ & $P$ \\
\hline & & $\%$ & $n l / \min$ & & \\
\hline \multirow[t]{2}{*}{13} & 1 & 37.2 & 2.64 & & \\
\hline & 2 & 8.7 & 0.77 & & \\
\hline \multirow[t]{6}{*}{14} & 1 & 34.9 & 0.96 & & \\
\hline & 2 & 40.6 & 1.89 & & \\
\hline & 3 & 35.5 & 1.25 & & \\
\hline & 4 & 46.7 & 2.76 & & \\
\hline & 5 & 9.4 & 0.91 & & \\
\hline & 6 & 30.6 & 1.49 & 0.73 & $0.1>P>0.05$ \\
\hline \multirow[t]{4}{*}{15} & 1 & 48.1 & 1.41 & & \\
\hline & 2 & 22.4 & 1.22 & & \\
\hline & 3 & 28.1 & 0.70 & & \\
\hline & 4 & 22.6 & 0.78 & 0.63 & $P>0.1$ \\
\hline \multirow[t]{2}{*}{16} & 1 & 18.7 & 0.54 & & \\
\hline & 2 & 29.0 & 0.68 & & \\
\hline \multirow[t]{4}{*}{17} & 1 & 50.8 & 1.37 & & \\
\hline & 2 & 39.3 & 0.74 & & \\
\hline & 3 & 31.4 & 0.53 & & \\
\hline & 4 & 12.0 & 0.00 & 0.98 & $0.025>P>0.01$ \\
\hline \multirow[t]{6}{*}{18} & 1 & 19.7 & 0.16 & & \\
\hline & 2 & 41.3 & 2.24 & & \\
\hline & 3 & 17.3 & 1.06 & & \\
\hline & 4 & 24.6 & 1.23 & & \\
\hline & 5 & 26.8 & 1.06 & & \\
\hline & 6 & 23.5 & 1.11 & 0.84 & $0.05>P>0.025$ \\
\hline
\end{tabular}

$P$ values express the significance of the calculated linear regression lines (least squares method) shown in Fig. 1.

* Correlation coefficient.

by pinocytotic vacuoles would result in the transfer of inulin from the interstitial space into the lumen as readily as sucrose. Such was not observed.

A second extracellular pathway might have been via the lateral interspaces between the epithelial cells and through the tight junction at the apical end of these interspaces (14). A number of recent observations have suggested that the lateral interspaces might provide an important site for passive movement of water (15) and ions $(7,14,16,17)$ across the renal tubules as well as other epithelial membranes (18-23). Windhager, Boulpaep, and Giebisch (17) found that an extracellular electrical shunt of low resistance exists across the necturus proximal tubule, and Giebisch (14) has proposed a cell model in which the lateral intercellular spaces and the tight junction constitute the anatomical pathway for this electrical shunt. In view of these observations and the anatomical structure of the epithelium it seems reasonable to assume that the most likely route of entry of the sucrose into the tubular lumen in the present expiremnts was via the lateral interspaces.

The precise mechanism for the entry of sucrose into the lumen during renal vein constriction is not certain, but most likely was that of passive diffusion down a concentration gradient. The observations are consistent with the view that the pore size of a limiting membrane in the region of the tight junction had enlarged enough to admit sucrose molecules but not enough to admit inulin. It is theoretically possible that the pore size of a membrane might increase by the coalescence of smaller pores, thus allowing large molecules which had previously been excluded to pass through the membrane without changing the over-all area available for diffusion of smaller, normally unrestricted molecules and water. If this were the case, the increased permeability to sucrose might have occurred without any accompanying increase in the 
permeability to sodium and water. Under such circumstances, the present experimental observations would not relate to the inhibition of sodium and water reabsorption induced by renal vein constriction. Although this possibility cannot be excluded, studies on changes in membrane permeability induced by hypertonic solutions have indicated that when the permeability of the renal tubules or other epithelial membranes is increased to extracellular solutes, the permeability to sodium and water also increases $(17-19,23)$. Also in saline-loaded necturus, droplets of isotonic raffinose (mol wt 594) injected into the proximal tubular lumen show an accelerated rate of expansion followed by accelerated contraction, as compared with hydropenic control animals (24). The expansion phase is due to the influx of salt and water, whereas the contraction phase is due to absorption of raffinose and water. Thus, saline loading apparently increases the permeability of the necturus tubule to sodium and water as well as to raffinose.

If the increase in permeability of the proximal tubule to sucrose in the RVC rats was accompanied by an increased permeability to sodium and water, enhanced passive back-diffusion of sodium and water into the tubular lumen might be expected. It has been proposed by Diamond and Bossert (25) that a hypertonic salt solution is generated near the apical end of the lateral interspaces due to active sodium transport into this space, and some recent experimental observations by Machen and Diamond (26) support the proposal. Although in the model of Diamond and Bossert the hypertonic fluid is

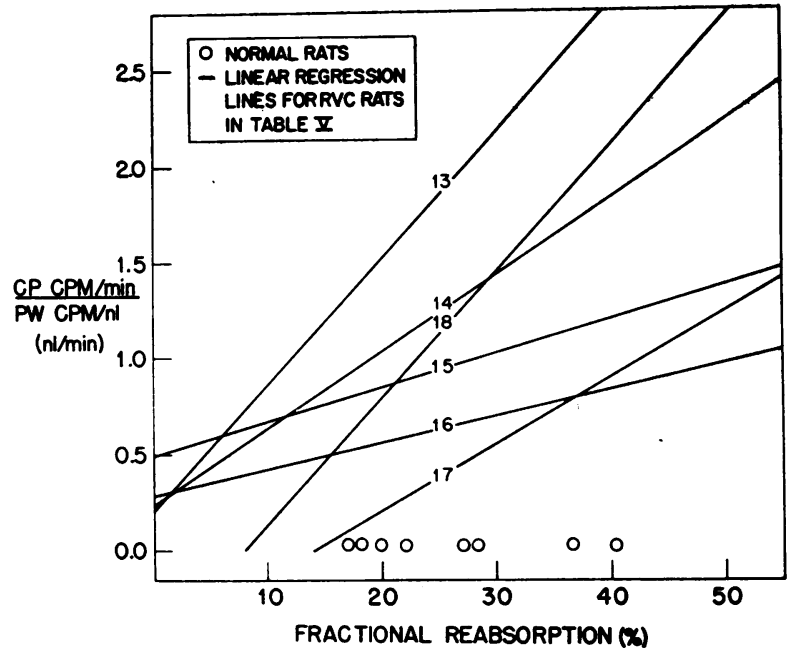

Figure 1 Appearance of sucrose- ${ }^{14} \mathrm{C}$ in isolated perfused segments of rat proximal tubules. The counts in the collected perfusate (CP) were factored by the plasma water (PW) count. Fractional reabsorption, taken as an estimate of the length of perfused segments, was measured with inulin- ${ }^{8} \mathrm{H}$.

conceived of as providing a mechanism for movement of sodium in the direction of reabsorption (toward the basal surface of the cell), it seems reasonable that it might also be involved in determining back-diffusion of sodium into the lumen under appropriate conditions of permeability. The reduction in net sodium reabsorption by the proximal tubule observed during renal vein constriction

TABLE VI

Appearance of Inulin ${ }^{14} C$ in Perfused Proximal Tubules of $R V C$ Rats

\begin{tabular}{|c|c|c|c|c|c|c|c|c|c|c|}
\hline $\begin{array}{l}\text { Exp. } \\
\text { No. }\end{array}$ & $\begin{array}{l}\text { Tubule } \\
\text { No. }\end{array}$ & $\begin{array}{l}\text { Volume of } \\
\text { collection }\end{array}$ & $\begin{array}{l}\text { Perfusion } \\
\text { rate }\end{array}$ & $\begin{array}{l}\text { Collection } \\
\text { rate }\end{array}$ & $\begin{array}{l}\text { Fractional } \\
\text { reabsorption }\end{array}$ & $\mathrm{CP} \mathrm{cpm}$ & $P$ & $\begin{array}{c}\mathrm{PW} \\
\mathrm{cpm} / \mathrm{nl}\end{array}$ & $\begin{array}{c}\mathrm{CP} \\
\mathrm{cpm} / \mathrm{min}\end{array}$ & $\frac{\mathrm{CP}(\mathrm{cpm} / \mathrm{min})}{\mathrm{PW}(\mathrm{cpm} / \mathrm{nl})}$ \\
\hline & & $n l$ & $n l / \min$ & $n l / \min$ & $\%$ & & & & & $n l / m i n$ \\
\hline \multirow[t]{5}{*}{21} & 1 & 28.3 & 9.0 & 7.1 & 21.7 & -0.128 & NS & 0.363 & & \\
\hline & 2 & 53.0 & 17.7 & 13.3 & 25.1 & 0.097 & NS & 0.388 & & \\
\hline & 3 & 83.0 & 25.9 & 20.8 & 19.7 & 0.928 & $<0.05$ & 0.397 & 0.232 & 0.583 \\
\hline & 4 & 102.5 & 34.0 & 25.6 & 24.7 & 0.006 & NS & 0.403 & & \\
\hline & 5 & 77.7 & 26.8 & 19.4 & 27.5 & 1.081 & $<0.05$ & 0.275 & 0.270 & 0.982 \\
\hline \multirow[t]{4}{*}{22} & 6 & 68.9 & 20.0 & 13.8 & 31.3 & 0.449 & NS & 0.215 & & \\
\hline & 7 & 95.4 & 24.1 & 19.1 & 20.7 & -0.436 & NS & 0.315 & & \\
\hline & 8 & 93.7 & 30.5 & 23.4 & 23.2 & 0.319 & $\mathrm{NS}$ & 0.370 & & \\
\hline & 9 & 77.7 & 27.1 & 19.4 & 28.3 & 1.064 & $<0.05$ & 0.467 & 0.266 & 0.569 \\
\hline \multirow[t]{5}{*}{23} & 10 & 72.4 & 27.3 & 18.1 & 33.7 & 0.570 & NS & 0.551 & & \\
\hline & 11 & 49.5 & 13.3 & 9.9 & 25.5 & 0.870 & $<0.05$ & 0.526 & 0.174 & 0.330 \\
\hline & 12 & 77.7 & 18.0 & 15.5 & 13.7 & 0.095 & NS & 0.503 & & \\
\hline & 13 & 70.7 & 24.6 & 17.7 & 28.3 & 0.407 & NS & 0.714 & & \\
\hline & 14 & 65.4 & 22.0 & 16.3 & 25.8 & -0.461 & NS & 0.806 & & \\
\hline \multirow{2}{*}{\multicolumn{2}{|c|}{$\begin{array}{l}\text { Mean } \\
\pm \mathrm{SE}\end{array}$}} & 72.6 & 22.9 & 17.1 & 24.9 & 0.347 & & 0.450 & 0.236 & 0.616 \\
\hline & & \pm 5.2 & \pm 1.8 & \pm 1.3 & \pm 1.4 & \pm 0.138 & & \pm 0.042 & \pm 0.020 & \pm 0.315 \\
\hline
\end{tabular}


might thus be the result of an increase in passive backdiffusion of sodium down a concentration gradient from the lateral interspaces into the lumen due to an increase in the permeability of the tight junction to sodium. Although this might be the entire explanation, the present observations do not exclude the possibility that RVC in some way inhibits the active sodium pump mechanism. Further studies are indicated to elucidate this question and the mechanism by which RVC alters the permeability of the tubular epithelium.

\section{ACKNOWLEDGMENTS}

We gratefully acknowledge the able technical assistance of Mr. Bertrand F. Mutz.

This research was supported by grants from the U. S. Public Health Service (RO1 HE 05770-10) and the New York Heart Association. Dr. Yarger is supported by a Special Fellowship from the U. S. Public Health Service (1-FO3-AM-43, 066-01).

\section{REFERENCES}

1. Earley, L. E., and R. M. Friedler. 1966. The effects of combined renal vasodilatation and pressor agents on renal hemodynamics and the tubular reabsorption of sodium. J. Clin. Invest. 45: 542.

2. Earley, L. E., J. A. Martino, and R. M. Friedler. 1966. Factors affecting sodium reabsorption by the proximal tubule as determined during blockade of distal sodium reabsorption. J. Clin. Invest. 45: 1668.

3. Martino, J. A., and L. E. Earley. 1967. Demonstration of a role of physical factors as determinants of the natriuretic response to volume expansion. J. Clin. Invest. 46: 1963.

4. Lewy, J. E., and E. E. Windhager. 1968. Peritubular control of proximal tubular fluid reabsorption in the rat kidney. Amer. J. Physiol. 214: 943.

5. Koch, K. M., H. S. Aynedjian, and N. Bank. 1968. The effect of acute hypertension on sodium reabsorption by the proximal tubule. J. Clin. Invest. 47: 1696.

6. Bank, N., K. M. Koch, H. S. Aynedjian, and M. Aras. 1969. Effect of changes in renal perfusion pressure on the suppression of proximal tubular sodium reabsorption due to saline loading. J. Clin. Invest. 48: 271.

7. Windhager, E. E., J. E. Lewy, and A. Spitzer. 1969. Intrarenal control of proximal tubular reabsorption of sodium and water. Nephron. 6: 247.

8. Gottschalk, C. W., and M. Mylle. 1956. Micropuncture study of pressures in proximal tubules and peritubular capillaries of the rat kidney and their relation to ureteral and renal venous pressures. Amer. J. Physiol. 185: 430.
9. Windhager, E. E., and G. Giebisch. 1961. Micropuncture study of renal tubular transfer cf sodium chloride in the rat. Amer. J. Physiol. 200: 581.

10. Bank, N., and H. S. Aynedjian. 1965. A micropuncture study of renal bicarbonate and chloride reabsorption in hypokalaemic alkalosis. Clin. Sci. 29: 159.

11. Steinitz, K. 1940. The renal excretion of sucrose in normal man; comparison with inulin. Amer. J. Physiol. 129: 252.

12. Davson, H. 1959. A Textbook of General Physiology. Little, Brown \& Co., Inc., Boston. 2nd edition. 277.

13. Bentzel, C. J., B. Parsa, and D. K. Hare. 1969. Osmotic flow across proximal tubule of Necturus: correlation of physiologic and anatomic studies. Amer. J. Physiol. 217: 570.

14. Giebisch, G. 1969. Functional organization of proximal and distal tubular electrolyte transport. Nephron. 6: 260.

15. Grantham, J. J., C. E. Ganote, M. B. Burg, and J. Orloff. 1969. Paths of transtubular water flow in isolated renal collecting tubules. J. Cell Biol. 41: 562 .

16. Giebisch, G. 1968. Some electrical properties of single renal tubule cells. J. Gen. Physiol. 51 (5, Pt. 2) : 315.

17. Windhager, E. E., E. L. Boulpaep, and G. Giebisch. 1966. Electrophysiological studies on single nephrons. Proc. Int. Congr. Nephrol. 3rd. 1: 35.

18. Ussing, H. H., and E. E. Windhager. 1964. Nature of the shunt path and active sodium transport path through frog skin epithelium. Acta Physiol. Scand. 61: 484.

19. Ussing, H. H. 1966. Anomalous transport of electrolytes and sucrose through the isolated frog skin induced by hypertonicity of the outside bathing solution. Ann. N.Y. Acad. Sci. 137: 543.

20. Franz, T. J., and J. T. Van Bruggen. 1967. Hyperosmolarity and the net transport of nonelectrolytes in frog skin. J. Gen. Physiol. 50: 933.

21. Franz, T. J., W. R. Galey, and J. T. Van Bruggen. 1968. Further observations on asymmetrical solute movement across membranes. J. Gen. Physiol. 51: 1.

22. Biber, T. U. L., and P. F. Curran. 1968. Coupled solute fluxes in toad skin. J. Gen. Physiol. 51: 606.

23. Urakabe, S., J. S. Handler, and J. Orloff. 1970 Effect of hypertonicity on permeability properties of the toad bladder. Amer. J. Physiol. 218: 1179.

24. Boulpaep, E. L. 1969. Presented at Symposia on Regulation of Sodium Excretion, The American Society of Nephrology Meeting, Washington, D. C. Dec. 1-2.

25. Diamond, J. M., and W. H. Bossert. 1967. Standing gradient osmotic flow. A mechanism for coupling of water and solute transport in epithelia. J. Gen. Physiol. 50: 2061.

26. Machen, T. E., and J. M. Diamond. 1969. An estimate of the salt concentration in the lateral intercellular spaces of rabbit gall-bladder during maximal fluid transport. J. Membrane Biol. 1: 194. 